\title{
On Instructional Resources for Teaching Special Needs Children in Abia State, Nigeria
}

\author{
Theresa Nnennaya Kanno, Jane A.E Onyeachu \\ Abia State College of Education Technical Arochukwu \\ Abia State, Nigeria
}

\begin{abstract}
This abstract focuses on availability and utilization of instructional resources in teaching Special Needs Children in Abia State, Nigeria. A twenty-item check list was employed for data collection while percentage was used for analysis of data. Findings revealed that $40 \%$ of the approved resources were availed while $60 \%$ of same was not. This implies, inter alia, that effective utilization cannot go beyond $40 \%$. It is, therefore, recommended that all relevant resources should be availed to teachers and pupils. Equally, it is suggested that all categories of Special Needs children, namely, deaf, dumb, dawn syndrome, autism should not be clustered into one classroom with non-specialist teacher teaching them. Thus, more individualized teaching as per the nature of needs of children in the class should be adopted.
\end{abstract}

\section{Introduction}

Instructional resources are indispensable for effective teaching and learning in all institutions for all categories of learners. They (instructional resources) facilitate and enhance learning process. This, therefore, underscores the need to make instructional resources available to all groups of learners especially the physically challenged who because of one handicap or the other cannot function effectively without special facilities in the classroom. Since such resources make teaching and learning easy and interesting they also serve as complementary channels of effective communication in the classroom.

This paper explores the availability and utilization of instructional resources for teaching Special Needs children in Abia State, Nigeria, by focusing on the following sub-headings:

1) Importance of Instructional Resources in Teaching Special Needs Children;

2) The Need for Availability and Effective Utilization of Instructional Resources;

3) Some Instructional Resources Required and their Degree of Availability;
4) Conclusion and Recommendations.

\section{Importance of Instructional Resources in Teaching Special Needs Children}

Instructional Resources simplify teaching and learning especially for Special Needs children who have one type of physical cum mental challenge or need. Iwuama [6] affirmed that education of children and adults who have learning difficulties because of different sorts of handicaps should be done with adequate and relevant instructional resources. Ikpeazu and Onwuama [5] equally emphasized that for effective education of the hearing impaired, there is need for the provision of adequate instructional resources for teaching. Some resources include hearing aid, mirrors and charts showing demonstrations of mouth and tongue positions. Ikpeazu and Onwuama further emphasized that when hearing aid is introduced early, for instance, it will enable the impaired (Special Needs) acquire basic communication skills. This fact underscores the need to make sure that instructional resources are available and at the same time utilized. As National Centre for learning Disability Policy Brief [9] retrieved on line affirms:

Accessible Instructional Materials (AIM) are specialized formats of curricular content that can be used by and with print-disabled learners. They include formats such as Braille, audio, large print, and electronic text. The 2004 reauthorization of the individuals with Disabilities Education Act ("IDEA 2004") introduced provisions pertaining to the establishment of the National Accessibility Standard ("NIMAS") and the National Instructional Materials Access Centre ("NIMAC"), which have the potential to improve the production and delivery of accessible instructional materials for students with print disabilities. Although students with learning disabilities could clearly benefit from these provisions, it is likely that many are being excluded from the NIMAS/NIMAC process as a result of limiting and confusing eligibility criteria. Under IDEA, section 504 
of the Rehabilitation Act of 1973 ("Section 504"), and Title II of the Americans with Disabilities Act ("ADA"), school districts have an obligation to ensure the timely provision of appropriate accessible instructional materials for all students with disabilities who require such materials because of their disability-related needs, regardless of whether the students are NIMAS/NIMAC eligible.

In order to enhance cum facilitate learning for learners with special needs, the school environment has to be conducive and thus the task of providing instructional resources becomes imperative if not mandatory. This is because relevant resources are very important and instrumental to improved performance. The key providers and utilizers of these instructional resources are the teachers. It is a well-known fact that an effective teacher is, inter alia, a competent and efficient professional who always strives to attain all stipulated objectives within a given classroom despite the peculiar challenges of the learners. Hence, an effective teacher should be trained in the provision of emotional support for learners, prudence in time management and production of results as he/she matches curriculum contents with learner's ability. These can easily be achieved through the actualization of the importance cum production and utilization of instructional resources, especially as they concern special needs children.

Emphasizing the importance of availability and utilization of instructional materials for teaching special needs children, Masoodi and Ban [8] opined that employing instructional materials cum good instructional strategies is one of major ways of encouraging the special needs children to learn. To Horn and Barsness, Instructional materials are intended for use with the educable mentally handicapped students who are mainstreamed into ordinary classes. Hence, resourceful teachers place optimal priority on the importance of resources. Focusing on the same issue, Association of America [3] upheld the view that activities for children with different handicap should be made activity oriented using viable, colourful and problem solving instructional resources. These resources are very important because, learning-disabled youngsters have inherent difficulty in learning abstract terms and concepts.

The Association advises that with reading problems one should use text books on tape, available through recording for the Blind and Dyslexic will improve their performance in the classroom. Hence, text books on tape are of necessity and of great importance for teaching the special needs (blind). A clear look at the importance of availability and utilization of instructional resources underscores the need for this study. This is because persons with special needs which include all special needs children are entitled to be provided with special educational services in order to enable them to learn effectively. These special services definitely include provision of instructional resources.

\section{Need for Availability and Utilization of Instructional Resources}

Instructional Resources especially for teaching children with special needs cannot be over emphasized. America Red Cross (2012) duly stressed the need for sign language textbooks and sign language pictures and diagrams. To them, [2] sign language is a form of language used by people who are deaf or who have hearing impairment concepts and ideas are represented through the use of manual signs, finger spelling and symbols. On that note, sign language textbooks are indispensable resources for effective teaching. Their availability, adequacy and utilization are very necessary. Learning difficulties experienced by Special Needs children are worrisome whether they are mainstreamed, integrated or separated in the classroom. There is need to employ relevant useful resources which will enhance effective teaching and learning. The problem of the availability, adequacy and effective utilization becomes of great concern.

Accessible Instructional Materials 101 Special Education [1] avails this guide on students with encountering difficulty: by posing these questions:

- Does the student have difficulty seeing the material? (Bindness or low vision)

- Does the student have difficulty physically manipulating the material? (Orthopedic impairment)

- Does the student have physical stamina necessary? (e.g. sitting upright, alertness) (other health impairments)

- Does the student have difficulty decoding text/recognizing words?

- Does the student have difficulty with fluency?

- Does the student lose the place while reading?

- Does the student have difficulty with comprehension skills?

This ensures availability and utilization of resources. It further serves as guide in ensuring that students encounter little or no difficulty while utilizing them. To that regard, this study, therefore, explores availability and utilization of instructional resources for teaching Special Needs children in Abia State, Nigeria, as indicated earlier. 
Specifically, the study seeks to determine:

i. The extent instructional resources are available to teachers for effective teaching of Special Needs children in Abia State, Nigeria.

ii. The extent teachers utilize instructional resources in teaching Special Needs children in Abia State, Nigeria.

iii. The extent teachers teaching Special Needs children are trained in the use of available instructional resources.

The findings of this study are expected to provide information on the need to provide needed instructional resources for effective teaching of special needs children. The findings are equally expected to provide information on the extent teachers teaching special needs children benefit from teachers' professional development programmes meant for improving the performance of teachers' skills focusing on special education.

They (findings) are also expected to provide information which will help stakeholders in education to create more training opportunities for the teachers teaching Special Needs children. It is also believed that the findings will provide useful guide to the teachers on the relevant instructional resources for teaching Special Needs children and equally enable them to appreciate the need for greater teacher effectiveness. It is further expected that parents and guardians of children with special needs will draw insights from the thrust of this paper. Researchers may also wish to explore the availability, adequacy and utilization of instructional resources in other localities and schools.

Finally, the findings of the study will provide information to the society at large on the various ways of teaching the special needs instead of allowing them to waste in the society.

\section{Some Instructional Resources Required and their Degrees of Availability}

A list of twenty-item approved instructional resources was generated by the teachers teaching children with special needs. They, equally, indicated the availability or otherwise of each item (see Table 1 ). The findings of the study revealed that out of twenty instructional resources expected to be in special education classrooms, eight (8) were available. This represents $40 \%$. That means that $40 \%$ of the resources were available in the school. Teachers confirmed that the available resources are being effectively utilized. They also confirmed that they (teachers) are trained on the effective utilization of those instructional resources. They, however, requested for more regular workshops and seminars on Special Needs Education for continuous update of knowledge.

It was equally revealed that pupils taught with instructional resources learn better than those taught without instructional resources. This is evident in their cheerful looks on their (learners') faces when interacting with resources availed to them. A case in point was their delight in watching themselves in the I-pad recording used during the conduct of this study. However, in some schools, children with special needs are in the same classroom with other children, most times with a non-specialist in Special education being the classroom teacher. Equally, even though, resources may be available, all children with special needs are grouped together in one class. Thus, in that same class, the deaf, dumb, dawn syndrome, autism, etc. stay together. There is need, therefore, to group them accordingly and in line with their peculiar special needs with their specialistteacher. Teachers affirmed that pupils taught using sign language textbooks and picture of signs performed better than those taught in integrated classroom where the special needs children are taught together with vocalized words without instructional materials. This affirmation is a clear indication that relevant instructional resources are indispensable in teaching the Special Needs children. Their degrees of availability, adequacy and effective implementation become sine qua non in yielding expected result in pedagogy.

\section{Conclusion and Recommendations}

The study notes that for effective teaching of children with special needs, variety of relevant instructional resources should be provided in all schools meant for training them. All hands should be on deck in providing adequate instructional resources for teaching the Special Needs children. It is, therefore, recommended that:

1) All stipulated instructional resources should be availed to schools for effective teaching of Special Needs children.

2) Teachers should utilize all availed instructional resources effectively in teaching in order to obtain maximum result.

3) Federal and State Government should frequently organize seminars, conferences and capacity building workshops for teachers teaching children with special needs.

4) Parents and other stakeholders in education should assist in providing instructional resources by ensuring safe manipulation of such resources 
Table 1. List of instructional resources and availability

\begin{tabular}{|c|c|c|c|}
\hline S/No & Instructional Resources & Approved & Available \\
\hline 1. & Auditory Aids & $\sqrt{ }$ & \\
\hline 2. & Joy of Sign Language Book & $\sqrt{ }$ & $\sqrt{ }$ \\
\hline 3. & Mathematical Sets (Shapes) & $\sqrt{ }$ & \\
\hline 4. & Fractional Shapes (Square, Triangle, etc) & $\sqrt{ }$ & \\
\hline 5. & Flash Cards & $\sqrt{ }$ & \\
\hline 6. & Alphabetical Chart & $\sqrt{ }$ & \\
\hline 7. & American Sign Language Alphabet (Chart) & $\sqrt{ }$ & $\sqrt{ }$ \\
\hline 8. & Computer Set & $\sqrt{ }$ & \\
\hline 9. & TV Set/DVD & $\sqrt{1}$ & \\
\hline 10. & Sign Language Films & $\sqrt{ }$ & $\sqrt{ }$ \\
\hline 11. & Counting Sticks & $\sqrt{ }$ & $\sqrt{ }$ \\
\hline 12. & Bricks Block & $\sqrt{1}$ & \\
\hline 13. & Ruler Set & $\sqrt{ }$ & $\sqrt{ }$ \\
\hline 14. & Clock face for teaching time & $\sqrt{1}$ & \\
\hline 15. & Toys & $\sqrt{ }$ & \\
\hline 16. & Exercise Books & $\sqrt{ }$ & $\sqrt{ }$ \\
\hline 17. & Pencils/Biros & $\sqrt{ }$ & $\sqrt{ }$ \\
\hline 18. & Crayons & $\sqrt{ }$ & \\
\hline 19. & Wall Charts & $\sqrt{ }$ & $\sqrt{ }$ \\
\hline 20. & Maps & $\sqrt{ }$ & \\
\hline
\end{tabular}

especially when their children/wards are at home doing one Home Work or the other.

5) Teachers and their pupils should, equally, provide instructional resources available within their immediate environment in order to complement the efforts of Government in that regard.

\section{References}

[1] Accessible Instructional Materials 101 EMSC Special; http://www.p12.nysed.gov/specialed/aim aim101.htm. (Access date: 29 October, 2015).

[2] American Red Cross, (2002). The Joy of Sign Language Assisting people with Disabilities. America: American Red Cross.

[3] Association of America, (2015). Learning Disabilities Association of America at 4156 Library Road Pittsburg; www.idanatl.org (Access date: 14 July, 2015).

[4] Horn, F. M. and Barsness, A. O. Eric (2015) Instructional Materials for use with Educable mentally Retarded; http://eric.gov/?id=ED112264. (Access date: 29 October, 2015)

[5] Ikpeazu, V. and Onwuama, M.E., (2003). Hearing Impairment in Iwuama, B.C. and Ekwe,
A.O. (Eds.). Exceptional Children Education, Owerri: Versatile Publishers 81-99.

[6] Iwuama, B.C., (2003). Exceptionality and Special Education in Iwuama, B.C. and Ekwe, A.O. (Eds.) Exceptional Children and Special Education, Owerri: Versatile Publishers 1-34.

[7] Kanno, T.N., (2012). The Image of An Effective Teacher in Contemporary Nigerian Society. Being a Guest Lecture at First College Seminar of the Federal College of Education (Technical), Umunze, Anambra State held at the College Multi-Purpose Auditorium on Thursday, June 28.

[8] Masoodi, B. and Ban, J.R. (2015). Teaching the Visually Handicapped in Regular Classes, http://www.nichev.org/disabinf.asp\#fsia

(Access date: 10 July, 2015).

[9] National Centre for Learning Disabilities Policy Brief retrieved online from cisamossb.ohgov/docs/ brochurob/misc/articles/aimfrLD/df. (Access date: 29 October, 2015).

[10] Onyeachu, J.A.E., (2008). Learning Disabilities and Challenges in the School Environment. A Journal of the Nigerian Council of Educational Psychology Awka: Nigeria Council of Educational Psychologists 1(I), 226-236. 